\title{
Adult Dental Health Surveys: 40 years on
}

\author{
J. J. Murray $\mathrm{CBE}^{1}$
}

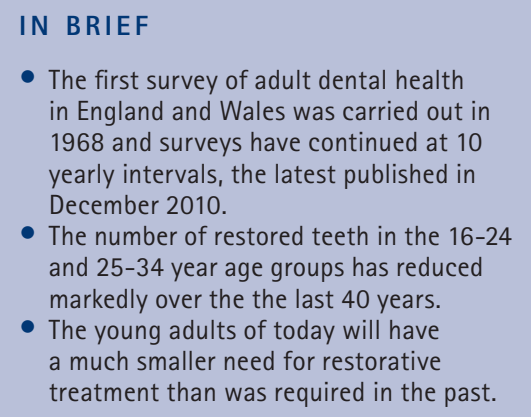

- The first survey of adult dental health in England and Wales was carried out in 1968 and surveys have continued at 10 yearly intervals, the latest published in mber 2010.

The young adults of today will have treatment than was required in the past.

A comparison of the results of the Adult Dental Health Surveys in England and Wales in 1968 and England, Wales and Northern Ireland in 2009 shows marked improvements in many aspects of oral health. Edentulousness in adults aged 16 years and over has reduced from 37\% to 6\%. Dentate adults today have 9 to 10 more sound teeth in all age groups up to 44 years, than was the case 40 years ago. The number of decayed or unsound teeth has halved in every age group between 1968 and 2009.

A news release from the Office of National Statistics concerning the 2009 Adult Dental Health Survey was published in December 2010. ${ }^{1}$ The headline was 'Nearly one in five women suffers extreme dental anxiety'. Focusing on dental anxiety may well make headline news, but I would like to take a wider perspective by comparing some of the findings of the present study with the first survey of Adult Dental Health in England and Wales in 1968. ${ }^{2}$

Professor Geoffrey Slack (London Hospital Medical College Dental School) was the driving force behind the first national survey, building on the work in Darlington and Salisbury and published in a report Demand and need for dental care, by Bulman and Slack and colleagues in 1962. ${ }^{3}$ Professor Peter James (Birmingham) and Professor Douglas Jackson (Leeds) were also involved in the planning of the national study. Three young men (who hoped to pursue academic careers in dentistry) carried out the pilot studies and acted as reserve examiners for the main survey. They were Jeremy Hardie, Roger Anderson and myself.

The headline in 1968 was that 37\% of the population in England and Wales over

${ }^{116}$ Regency Way, Darras Hall, Newcastle-upon-Tyne, NE20 9AU

Correspondence to: Professor John Murray CBE Email:profjohnmurray@gmail.com

\section{Refereed Paper}

Accepted 9 September 2011

DOI: 10.1038/sj.bdj.2011.903

${ }^{\circledR}$ British Dental Journal 2011; 211: 407-408

\begin{tabular}{|c|c|c|c|c|c|c|c|c|}
\hline \multirow[t]{2}{*}{$\begin{array}{l}\text { Age in } \\
\text { years }\end{array}$} & \multicolumn{2}{|c|}{$\begin{array}{l}\text { Mean no. } \\
\text { of teeth }\end{array}$} & \multicolumn{2}{|c|}{$\begin{array}{l}\text { Mean no. of sound } \\
\text { and untreated teeth }\end{array}$} & \multicolumn{2}{|c|}{$\begin{array}{l}\text { Mean no. of } \\
\text { restored, otherwise } \\
\text { sound teeth }\end{array}$} & \multicolumn{2}{|c|}{$\begin{array}{c}\text { Mean no. } \\
\text { of decayed or } \\
\text { unsound teeth }\end{array}$} \\
\hline & 1968 & 2009 & 1968 & 2009 & 1968 & 2009 & 1968 & 2009 \\
\hline $16-24$ & 26.8 & 28.6 & 16.4 & 25.9 & 8.3 & 1.8 & 2.1 & 0.9 \\
\hline $25-34$ & 24.5 & 28.8 & 13.5 & 23.7 & 8.6 & 3.8 & 2.4 & 1.2 \\
\hline $35-44$ & 21.6 & 27.6 & 12.5 & 20.1 & 6.8 & 6.6 & 2.3 & 0.9 \\
\hline $45-54$ & 17.4 & 26.0 & 10.2 & 15.1 & 5.1 & 9.9 & 2.1 & 1.0 \\
\hline $55-64$ & & 23.1 & & 11.9 & & 10.1 & & 1.0 \\
\hline $65-74$ & $14.7^{*}$ & 20.9 & $9.0^{*}$ & 10.5 & $3.5^{*}$ & 9.5 & $2.2^{*}$ & 0.9 \\
\hline 75-84 & & 17.1 & & 8.5 & & 7.5 & & 1.0 \\
\hline $\begin{array}{l}85 \text { and } \\
\text { over }\end{array}$ & & 14.0 & & 6.8 & & 6.3 & & 0.7 \\
\hline
\end{tabular}

"1968 survey only gave data for 55 and over (only 225 dentate adults in this age group)

the age of 16 years were edentulous. For 2009 only 6\% were edentulous, concentrated in those aged 65 years and over. In 1968, 2,658 adults were interviewed and had a dental examination, but because of the high proportion of edentulous people in the study, the number of dentate adults in the older age groups was fairly small, so most of the data were presented in two age bands, 16-34 year olds and 35 years and over. However, one table in Appendix D presented information in greater detail, enabling a comparison to be made of tooth condition in ten year age bands in 1968 with 2009 (Table 1). In the current survey, all ages up to 65-74 years had 21 or more standing teeth, whereas in 1968 only those up to 35-44 years still retained the majority of their teeth, a 30 year improvement. (the index of 21 or more standing teeth was introduced in the 1998 Adult Dental Health survey, as an indicator of a 'shortened dental arch', where partial dentures may not be required). There are now nine or ten more sound teeth in all age groups up to 44 years today than there were 40 years ago. The number of restored teeth has reduced dramatically in the 16-24 year and 25-34 year age groups. In 1968, 16-24-year-olds already had 8.3 restored teeth. That same cohort, 40 years later, had 10.1 restored teeth. This is not a large increase over 40 years, although it is appreciated that some restored teeth will have had further restorative care, some restored teeth will 
have been extracted and teeth originally sound will have been filled over the 40 year period. Looking forward to the next 40 years one can confidently predict that the young adults of today, with only 1.8 restored teeth on average, will have a much smaller need for restorative treatment due to decay than was required in the past. The number of decayed or unsound teeth has halved in every age group between 1968 and 2009.

The foresight of Professor Slack and his colleagues in the 1960s who persuaded the
Department of Health and Social Security to authorise a survey 'to provide information about the dental health of the community generally....2 ${ }^{2}$ resulted in a set of baseline data from which we can compare the condition of teeth in England and Wales over 40 years. National dental surveys today are much more sophisticated than they were 40 years ago. New assessments have been introduced to measure periodontal disease, occlusion and trends in dental attitude, experience and behaviour. The headline in the 2009 survey concerned dental anxiety, but the detail provides irrefutable evidence of the scale of the improvement of teeth since 1968. The dental profession has played its part in transforming the oral health of the country over the last 40 years.

1. The Health and Social Care Information Centre. Adult dental health survey 2009. London: Department of Health, 2010.

2. Gray P G. Todd J.E, Slack, G L, Bulman J S. Adult dental health in England and Wales in 1968. London: HMSO, 1970.

3. Bulman J S, Richards N D, Slack G L, Willoocks A J. Demand and need for dental care: a socio-dental study. London: The Nuffield Trust, 1962. 